\title{
Governing Insecurity: Democratic Control of Military and Security Establishments in Transitional Democracies
}

\author{
Cavin Cawthra and Robin Luckman (eds.)
}

London: Zed Books, 2003

340 pages

ISBN $\quad$ Hb 1842771485

$\mathrm{Pb} 1842771493$

In the post-Cold War era democratic institutions have widely come to be regarded as the only legitimate forms of governance. But the longstanding legacies of military rule cast a shadow over many newly instituted democratic regimes. Moreover, the fact that many societies have experienced an erosion of order and government disintegration under the pressures of violent conflict and internal war poses some intractable obstacles or challenges to the institutionalisation of democracy and human security.

Governing Insecurity is one of a three-book series that explores the politics of democratic transition in conflict-torn countries in the Developing World, focusing on the interplay between democratic institutions and democratic politics. The editors - one of whom is a leading South African scholar - specifically set out to explore the challenges of establishing democratic accountability and control of the military and other security establishments in countries that have been either the victims of authoritarian military rule or racked by violent internal conflict. In this regard, the editors bring together the work of leading scholars on military and security issues in the developing South and post-Communist East.

The main thrust of the editors is to ascertain how to assure democratic control of military and security institutions. Democratic control is not analysed in isolation, but is linked to the broader issues of good governance and of security sector transformation. The editors and contributing authors consider both successful democratic transitions and failed ones in countries as divergent as Sri Lanka, South Africa, Chile and Bosnia-Herzegovina. Half of the chosen countries are from 
Africa, which is appropriate, given that the challenges of governing insecurity are probably most acute in Africa.

The book is divided into four sections. The first is an introductory chapter that sets the scene by considering the global context in which debates about the governance of insecurity have taken place. It places democratisation in the context of post-Cold War transformations in global and regional security arrangements. It focuses on the emergence of new forms of military politics and new sources of conflict and insecurity - and spells out the implications for democratic transition.

The second section is devoted to case studies of transitional democracies, specifically South Africa, Nigeria, Ghana, Chile, together with a regional survey of Latin American transitions. South Africa is the only one of these cases where there was simultaneously a transition from armed conflict to democracy (although Guatemala, Colombia and other conflict-torn countries are considered in the Latin American chapter). This section examines the efforts to overcome the legacies of authoritarianism, to increase democratic control over military, police, paramilitary and intelligence structures, to assure their accountability for human rights abuses, and to develop appropriate security roles for them in a democratic setting. It singles out South Africa as one of the first - and most successful - examples of security sector reform in the post-Cold War period. At the same time, it is emphasised that in none of the other countries has it been possible to take progress towards democracy for granted. All of these cases have faced difficult decisions concerning military and security questions. In certain cases (notably Chile) democratic control has been delayed by authoritarian residues. In others (notably Nigeria) it is potentially challenged by the weakness of democratic institutions and the difficulties to cope with new sources of conflict and insecurity. The final part of this section specifically considers the lessons of democratic consolidation in Latin America, where the seeming retreat of the armed forces from the political domain has not necessarily meant increased democratic participation in governance, nor made the armed forces more accountable, nor ended political and military violence.

The third section of the book considers the peculiar complex problems of democratic control in Algeria, Sri Lanka, Sierra Leone, the Democratic Republic of Congo (DRC), Bosnia-Herzegovina and the countries of the Balkan region in general. In these countries one or more of the following have occurred: violent conflict has remained endemic; the democratic transition has failed or even been reversed; the security structures have fractured or disintegrated and been replaced by informal militias or external forces; or the state has collapsed. It is argued that under these conditions, the security sector reform agenda is usually by itself insufficient or can at best be very partially implemented. National reconstruction of the whole 
framework of public authority - not just reform of state security institutions - is needed, although it may be possible to carry out some reforms as part of the reconstruction process.

More specifically, it is pointed out that in the case of Algeria, political violence has been associated with a re-transition to authoritarianism within a military-dominated state. In Sri Lanka, a long established democracy has been weakened by protracted armed conflicts with both ethnic and class dimensions. Efforts to make the armed forces and police more accountable have been frustrated in a context where ruthless armed opposition has operated in conditions of impunity. In contrast, the violence in Sierra Leone, in the DRC and in Bosnia-Herzegovina has been linked to the fracturing of the state and its formal military and security establishments, which have been supplanted by dissident armies, paramilitary bodies, mercenaries and armed mafias.

This section of the book furthermore highlights the regional dimensions of security governance in chapters on the Balkans and Latin America, as well as in some national cases, notably Bosnia-Herzegovina, Sierra Leone and the DRC. In many cases the political and security predicaments of the countries studied are related to wider challenges within what may be termed 'regional security complexes'. The latter is often a relationship both of cause and effect as insecurity in one country feeds into that of another. Furthermore, it is difficult, if not impossible, for a country to carry out profound security reforms if its external environment is unstable and a security threat.

The fourth and final section of the book comprises a concluding chapter in which the editors compare the different efforts to reform military and security structures and to assure their democratic accountability. In an inductive approach they also draw appropriate conclusions for practical policy considerations. In what circumstances have reforms succeeded and when have they failed? On the one hand, the chapter focuses on the historical and contextual factors, which have facilitated or limited reform. On the other, it considers the political and policy choices made by governments, donors and international agencies, civil society groups and military and security establishments.

In sum, Governing Insecurity examines the governance of security - or in most cases insecurity - in developing and former communist countries that are riding, or at least are buffeted by, the jagged 'third wave' of global democratisation. As such, one of its central concerns is how to assure democratic control of military and security institutions. The point is clearly made that 'control' is not a simple concept and that it requires democratic institutions to be in place as well as a basic acceptance of democratic politics by the political leadership, civil servants and 
security personnel. State or civil control of military and security structures is not necessarily equivalent to democratic control. As is evident from the different case studies, it is perfectly possible to have civil control of the military that is nondemocratic, anti-democratic or even militaristic.

The book therefore rightly stresses that even democratic institutions do not necessarily deliver democratic governance, least of all in the security sector. Democratisation is a drawn-out process and it does not end with formal transition to an elected government. It is sometimes derailed or reversed, especially in conditions of national and regional insecurity. Another important point is the contention that democratic control of military and security institutions is strategic to democratisation for two main reasons: firstly because these institutions have a peculiar intimate relationship to political power and secondly because their security functions, including the management of insecurities that may be generated by democratisation, are essential for the survival of any democratic state.

It should also be noted that the editors have aimed to draw upon specific country experiences in an empirical approach, hoping to develop indigenous perspectives from both the South and the former communist countries. However, they expressly contend there can be no 'one fits all' solution to governing security in transitions, and that careful attention has to be paid to national variations. To this end, there is no linear road to democracy from authoritarianism which also implies that there is broader agreement about the end point than there is about the ways and means of getting there.

This said, the book is certainly a welcome edition to the growing literature on security sector reform that includes baseline 'good governance' norms in relation to security management. It adds value to the current body of knowledge by leaving the reader with the message that this is only part of the story, as explained above. Governing Insecurity consequently fills a gap in the literature on governance and development and provide students in the fields of democratic governance and civilmilitary relations with some refreshing insights into the challenges of establishing democratic accountability and control of military and security establishments in especially developing countries.

Prof Theo Neethling, Subject Group Political Science (Mil), Faculty of Military Science, Stellenbosch University 